PROBLEMS

OF EDUCATION

IN THE $21^{\text {st }}$ CENTURY

Volume 40, 2012

\title{
96 TEACHING, LEARNING, AND KNOWLEDGE BUILDING: THE CASE OF THE REMOTE NETWORKED SCHOOL INITIATIVE
}

\author{
Thérèse Laferrière, Sylvie Barma, Fernand Gervais, Christine Hamel \\ Université Laval, Québec, Québec, Canada \\ E-mail: Therese.Laferriere@fse.ulaval.ca, Fernand.Gervais@fes.ulaval.ca, Christine. \\ Hamel@fse.ulaval.ca \\ Stéphane Allaire \\ Université du Québec à Chicoutimi, Saguenay, Québec, Canada \\ E-mail: Stephane_Allaire@uqac.ca \\ Alain Breuleux \\ McGill University, Montréal, Québec, Canada \\ E-mail: alain.breuleux@mcgill.ca
}

\begin{abstract}
The Remote Networked School (RNS)/ «École éloignée en réseau » is an initiative that aims at implementing an innovation with Internet-based technologies in support of teaching and learning as well as knowledge building in small rural schools. The first eight years of the RNS are examined applying Engeström's activity theory framework, and more specifically the concept of expansive learning wherein we document the 7 stages. Tensions and contradictions are identified to provide an "inside" understanding of what matters when new technologies designed to support co-teaching and co-learning within and between classrooms are introduced. Two activity systems or more shared the same object such that students would engage actively in collaborative online discourse for solving authentic problems. To this end the trajectory of the RNS initiative had to overcome contradictions. As a result an expansive learning cycle was documented.
\end{abstract}

Key words: activity theory, collaboration, expansive learning, remote networked school.

\section{Introduction}

Co-teaching and co-learning as well as knowledge building characterize the Remote Networked School (RNS)/ École éloignée en réseau ». It is the result of participatory design (Silva \& Breuleux, 1994) under the following circumstances: 1) The Quebec Ministry of Education (Canada) was searching (2001) for ways to improve small rural schools' learning environment with the use of information and communication technologies (ICTs) and contacted a knowledge transfer organization dedicated to ICT integration in workplace organizations (CEFRIO); 2) Francophone teachers were opposed to the delivery of online courses to K-12 students; 3) CRIRES' researchers (Centre for Research and Intervention for School Success) saw the opportunity for classroom-based designs that link computer, collaboration and pedagogy to prepare students for the knowledge age.

This paper presents a meso-level analysis of the unfolding of what came to become an innovation from an activity theory perspective. First, contextual, conceptual and methodological 
Thérèse LAFERRIÈRE, Sylvie BARMA, Fernand GERVAIS, Christine HAMEL, Stéphane ALLAIRE, Alain BREULEUX. Teaching, Learning, and Knowledge Building: The Case of the Remote Networked School Initiative

\author{
PROBLEMS \\ OF EDUCATION \\ IN THE $21^{\text {st }}$ CENTURY \\ Volume 40, 2012
}

background is provided. Second, the experiential trajectory of the RNS initiative is depicted. An analysis of the overcoming of contradictions over the eight-year period follows, and points to how they became a driving force to engage in change.

\title{
Background
}

Small rural schools (less then 100 students) were struggling with specific problems, mainly the cost of keeping them open, the lack of qualified human resources and interactions with few same-age students. Moreover, the Province of Quebec was undergoing an educational reform aiming at a better preparation for school learners of the 21 st Century. Cognitive, constructivist and socio-constructivist perspectives inspired this reform. The new national curriculum put in place in both elementary and secondary schools evolved to become a source of tensions and national debate regarding its application. As Engeström (1996) points out, learning environments are constantly changing because of the implementation of new curriculums or the interests of students themselves. Distributed cognition (Hollan, Hutchins, \& Kirsch, 2000; Salomon, 1993) in a single school, however, was insufficient to provide sufficient agency to align pedagogy with the goals of the reform, and reduce new tensions (see Engeström \& Miettinen, 1999). For teachers in remote rural areas it was difficult to access proper professional development, and possibilities for exchanging with colleagues about the meaning and ways of implementing the new curriculum were limited. Edwards (2008) has documented how it is difficult to bring about change among school social practices for a variety of reasons, such as the preservation of a school's operating rules, pressure to comply with curriculum requirements, or competition between schools.

University-school partnerships and teacher networks (Holmes Group, 1990; Laferrière et al., 2010; Lieberman, 2000) are key strategies when it comes to educational reform and innovation. At the onset, the RNS partnership included researchers and graduate students from two different universities - the research and intervention team (RIT). The partnership put forward the idea that collaborative digital platforms would support and stretch human interaction and, therefore, enhance the learning environment of small rural schools. The design activity began, and its goal was the enrichment of the learning environment at three pilot sites. For RIT, Bereiter and Scardamalia's $(1993,1994)$ designs were the more conclusive with respect to technology use, and the knowledge building epistemology, pedagogy, and technology oriented the professional development and collaborative research dimensions of the partnership. When school- and district-based participants took actions, however, they reflected their own theory in use (Schön, 1983). As pointed by Engeström \& Sannino (2010a), participants often take over the leading role in the intervention process and introduce a tension in the sense that they reformulate their tasks and change the course of what the interventionist has suggested. Here we are reminded of the following quote from Engeström and Sannino (2010b):

Traditional modes of learning deal with tasks in which the contents to be learned are well known ahead of time by those who design, manage and implement various programs of learning. When ... work processes and organizations, need to redefine themselves, traditional modes of learning are not enough. Nobody knows exactly what needs to be learned. (p. 3).

Nonetheless, a new form of activity began to take place within and between classrooms (Laferrière, Breuleux, \& Inchauspé, 2004). In its fourth phase (2008-2010) the initiative scaled up to 23 school districts.

The RSN initiative made it possible to trace the historical development of some inner contradictions using the theoretical lens of the model of a collective activity system. Although contradictions are not accessible directly, this empirical study allowed us to recognize their 
PROBLEMS

OF EDUCATION

IN THE $21^{\text {st }}$ CENTURY

Volume 40, 2012

manifestations through actions and words that generated tensions (Engeström \& Sannino, $2010 \mathrm{~b}$ ). As actors of the RNS made sense of new patterns of talk and actions, new usage of tools that were modelized, contradictions pushed the RNS into new phases of development. Contradictions are a foundational philosophical concept. They must not be confused with tensions, problems or conflicts. They are systemic and can only be grasped when analyzed within a dynamic system, not as separate entities since they consist of two forces that put the system at opposite directions (Miettinen, 2009). In such a way, they co-constitute each other. In order to identify them, one must trace the history of the system. That is what this study is aiming at presenting by focusing on the thirdnesses that emerged in the late years of the eightyear period.

\section{The Experiential Trajectory of the Design-based Research RNS Initiative}

As in any design-based research (Brown, 1992; Collins Joseph, \& Bielaczyc, 2004), research and intervention were to be closely linked. RIT put forward a first model: two collaborative tools, one for online written discourse (Knowledge Forum) and one for verbal interaction (iVisit, a multi-user desktop videoconferencing system); onsite/online professional development activities; research iterations (innovation conditions monitoring; use of the collaborative technologies, etc.); steering committee led by the deputy-minister in charge, and school district monitoring committee led by assistant superintendent. This model reflected topdown decisions but local bottom-up decisions were also understood to be necessary. Volunteer school districts, schools and teachers were invited to « mettre en œuvre » / « invent » the remote networked school, and not to « simply » implement, apply the model. The introduction of new tools, be they technological or conceptual, brought upon the learning environment a zone of challenge to be explored as it created a double bind between the use value and the exchange value of those tools. At the action level, the objectives were: 1) the teachers would use the collaborative tools to co-design learning activities for their classes (co-teaching) and 2) their students would also work collaboratively using the same tools (co-learning), and 3) engage in knowledge building.

During Phase One (2002-2004), participants were from three school districts (8 schools) and interacted onsite and online with RIT, the university-based research and intervention team being composed of members from Laval \& McGill universities. Written and verbal conversations unfolded between participants (school teachers, learners and administrators) from different schools or with RIT. The top-down decision made regarding tools had restricted to Knowledge Forum and iVisit the number of online tools (tools) used for research and collaboration purposes, and there were identified as second level tensions. Four iterations were designed to address tensions and develop better understanding of the technology innovation, conditions, teacher beliefs, activities conducted online (tools, discourse, roles, and routines), and learning outcomes, including student academic results. Phase One results were encouraging in both quantitative and qualitative terms regarding online interaction using iVisit; students had more room to express themselves. Knowledge building indicators were also encouraging at the two (out of three) sites that made use of Knowledge Forum. Teacher online discourse (peer-to-peer professional development) was analyzed during planning and/or reflection on online learning activities as regards teaching beliefs. Learning outcomes being quite satisfying, research attention turned to the scaling of collaborative processes (more participating schools and classrooms).

Phase Two (2004-2006) was dedicated to the interpretation of teacher and student online discourse displayed under the circumstances. Whereas the intent of the researchers (as subjects and interveners) was to rise the level of complexity with regards to the reading and writing process during and beyond project- and inquiry-based learning, networked classroom participating teachers' intent (as subjects and interveners, 13 sites, three universities and over 
Thérèse LAFERRIĖRE, Sylvie BARMA, Fernand GERVAIS, Christine HAMEL, Stéphane ALLAIRE, Alain BREULEUX. Teaching, Learning, and Knowledge Building: The Case of the Remote Networked School Initiative

\author{
PROBLEMS \\ OF EDUCATION \\ IN THE $21^{\text {st }}$ CENTURY \\ Volume 40, 2012
}

100 teachers involved) was first and foremost to understand the value of online tools to improve

the learning environment. By comparing the results of that phase to the situation at the beginning of the project, we were able to notice that the activity had undergone a change and addressed the third level of contradiction. The tensions were addressed especially during online conversation (iVisit support room), the six research iterations revolved around both types of preoccupations as well as on student interaction on Knowledge Forum, and at onsite meetings.

Phase Three (2006-2008) was a first test of sustainability and scalability with four school districts considered more advanced that the other 18 school districts also implementing the RNS model. Funding was reduced for all schools, except those belonging to the four school districts that had accepted to accelerate coping with sustainability and scalability challenges. The research focus turned to documenting student learning. In late Phase III and in Phase IV, The Knowledge Building International Project (KBIP) was at the forefront of the kind of progressive online discourse students have been capable of achieving. They walked on the knowledge building/ knowledge creation path as they contributed local data and inquired into one question or another under the umbrella theme of climate changes. Endangered animal species, water quality, and other sustainability issues have been inquired into, and results reported (Laferrière, Law, \& Montané, in press). Participants addressed the quaternary contradiction: They consolidated and reflected on the new practice.

Phase Four (2008-2010) called on school district superintendents' political will to institutionalize the RNS model before thinking of closing a small school within their district. The research team expanded to four universities, and an online multi-university graduate program was established (Laferrière et al., 2010). This was done mainly to contribute to the institutionalization process and to allow new teachers and pedagogical consultants who were not part of the RNS to join it. Moreover, it was also a way to provide additional professional development to participants already part of the initiative.

Table 1 resumes each phase of the RNS and Table 2 resumes both the research and intervention foci within each phase.

Table 1. Participation across RNS innovation phases.

\begin{tabular}{|l|c|c|c|c|}
\hline Participants & $\begin{array}{c}\text { Phase 1 } \\
(\mathbf{2 0 0 2 - 2 0 0 4 )}\end{array}$ & $\begin{array}{c}\text { Phase 2 } \\
(\mathbf{2 0 0 4 - 2 0 0 6 )}\end{array}$ & $\begin{array}{c}\text { Phase 3 } \\
\mathbf{( 2 0 0 6 - 2 0 0 8 )}\end{array}$ & $\begin{array}{c}\text { Phase 4 } \\
\mathbf{( 2 0 0 8 - 2 0 1 0 )}\end{array}$ \\
\hline School District & 3 & 13 & 22 & 23 \\
\hline Schools & 8 & 58 & 116 & 149 \\
\hline Teachers & 12 & 118 & 206 & 211 \\
\hline Students & 300 & 1500 & 2500 & 3000 \\
\hline
\end{tabular}


PROBLEMS

OF EDUCATION

IN THE $21^{\text {st }}$ CENTURY

Volume 40, 2012

100

\section{Table 2. Key progressive research and intervention design actions.}

\begin{tabular}{|c|c|c|}
\hline & Research & Intervention \\
\hline \multicolumn{3}{|c|}{ Object outcome: Design RNS among each site to enrich the learning environment } \\
\hline $\begin{array}{l}\text { Phase } 1 \\
(2002-2004)\end{array}$ & $\begin{array}{l}\text { - } \text { Identification of online activities and their } \\
\text { impact on learners' motivation and reading } \\
\text { skills } \\
\text { - Reflection on teachers' beliefs } \\
\text { - Monitoring of innovative conditions dis- } \\
\text { played in each site }\end{array}$ & $\begin{array}{l}\text { - Use of the tools for learning in coherence } \\
\text { with the new curriculum } \\
\text { - Design of project- and inquiry- based learn- } \\
\text { ing activities } \\
\text { - Knowledge building principles informed } \\
\text { teacher educators } \\
\text { - Link research results with the next step }\end{array}$ \\
\hline $\begin{array}{l}\text { Phase 2 } \\
\text { (2004-2006) }\end{array}$ & $\begin{array}{l}\text { - Reflection on student and teacher online } \\
\text { discourse } \\
\text { - Impact of the RNS professional develop- } \\
\text { ment on teachers' competencies }\end{array}$ & $\begin{array}{l}\text { - } \text { Authentic questioning and real ideas in the } \\
\text { online discourse } \\
\text { - } \quad \text { Sustaining progressive online discourse } \\
\text { - } \text { Rise-above discourse }\end{array}$ \\
\hline $\begin{array}{l}\text { Phase 3 } \\
(2006-2008)\end{array}$ & $\begin{array}{l}\text { Explicit presentation of the knowledge } \\
\text { building principles to participants } \\
\text { - Identification of sustainability and scalabil- } \\
\text { ity challenges } \\
\text { - Students learning (motivation, reading and } \\
\text { writing skills, progressive discourse) }\end{array}$ & $\begin{array}{l}\text { - Authentic questioning in the online discourse } \\
\text { in science and social studies (Hmelo-Silver } \\
\text { \& Barrows, 2008) } \\
\text { - Assessment of student discourse } \\
\text { - Development of students' explanation skills } \\
\text { - Knowledge Building international project }\end{array}$ \\
\hline $\begin{array}{l}\text { Phase } 4 \\
(2008-2010)\end{array}$ & $\begin{array}{l}\text { - } \text { Focus on learning outcomes } \\
\text { - Identification of the conditions for the insti- } \\
\text { tutionalization of the RNS model }\end{array}$ & $\begin{array}{l}\text { - Organization and management of the multi- } \\
\text { grade classroom } \\
\text { - Reification of the RNS teaching and learn- } \\
\text { ing model (pedagogical guide) }\end{array}$ \\
\hline
\end{tabular}

Some progress was manifest from phase to phase. In this paper, we focus on systemic tensions that would allow us to identify inner contradictions arising over the eight-year period. These contradictions will become driving forces pushing the RNS initiative forward in its development. Throughout the innovation process, the tensions and contradictions characterized and reflected both the RNS's successes and shortcomings insofar as co-teaching, co-learning, and knowledge building were concerned.

Barab, Barnett, \& Squire (2002) had paved the way by adopting Engeström's activity theory framework, thus providing an illustration of the essential tensions encountered during the redefinition of an astronomy course and a keen analysis of the dialectics that unfolded. Design research has to generate theory and connect it back to practice. This is a difficult research agenda: RIT had to deal with all the iterations and the amount of data collected (see also Yamagata-Lynch, 2007). Engeström's (1987) activity system analysis, with procedures that keep developing, was used to identify tensions that needed to be addressed within and between activity systems.

The two mediating/collaborative tools (iVisit and Knowledge Forum) were generating a rich data set. Borrowing Schön's reflective practitioner model (1983), teachers were invited to reflect on the adequacy between their pedagogical intents and the results obtained with the students in their classes. Emerging objects-outcomes became students' engagement in online discourse, and discourse quality as measured, for instance, by the type of activity conducted, the diversity of questions asked and the level of explanation. At most iterations, RIT provided online discourse analyses as evidence of progress or not regarding collaborative learning and 
Thérèse LAFERRIÈRE, Sylvie BARMA, Fernand GERVAIS, Christine HAMEL, Stéphane ALLAIRE, Alain BREULEUX. Teaching, Learning, and Knowledge Building: The Case of the Remote Networked School Initiative

knowledge building. It is out of online discussions with participants and between participants that tensions were identified. As the next section will demonstrate, some of them were resolved and others persisted.

\section{Documenting Tensions Introduced by New Tools}

The top-down decision made by the Ministry of Education to launch the RNS initiative, with its specific tools and related resources, reflected dissatisfaction with the status quo but not a « bottom-up desire » (see Looi, so, \& Chen's expression, 2010) to do things differently. The dissatisfaction level was neither high at the school district governance level nor at the school leadership level (Turcotte \& Hamel, 2008). However, because of the funding provided to volunteer school districts, this top-down decision did not become an explicit tension. Specific related top-down decisions generated manifest and localized tensions, especially the choice of the collaborative tools.

\section{iVisit as a tool for collaborative learning}

RIT chose the two collaborative tools, and that created a tension with school district information technology (IT) services (tension 1), and more so at some school districts than at others. One element had to do with the technical aspects of iVisit, one videoconference system used for oral communication between distant classrooms. RNS being schools located in rural regions, Internet bandwidth was not as fast or easily available as in cities. Bandwidth consumption was therefore an important stake to take into account. Priority went to tools that created a low demand on bandwidth. Otherwise, verbal communication between pupils and teachers would suffer. Tests conducted by an expert consultant showed iVisit was the best tool in this regard. In counterpart, iVisit runs with direct connection between computers, a mode of connection not very well supported by IT systems (proxies and firewalls) in school districts of the Province of Quebec. The issue was openly discussed onsite and/or online but some concerns remained unspoken, and the issue kept being vivid at some sites. People had their reasons for resisting adoption: they feared about network security. Some of them decided to tweak in some ways their regular network, thus leading RNS to run on a parallel network. In some other places, RIT became aware after a while that the configuration was only allowing schools from a same school district to communicate together using iVisit. Many times, during summer vacations, network configuration was reset. Teachers would arrive in the beginning of the following school year and discover iVisit was no longer working. Although they were motivated by the fundamental idea of the RNS, such issues were irritating and slowed down the growing of the RNS initiative as a whole for a number of years. The arrival of a webbased videoconferencing system resorbed some of the tension with the IT people but created some tension with teachers who used to iVisit and did not want to face having to change tool. Teachers voiced their concerns, which were addressed during onsite and online meetings.

For teachers who adopted the tool, a panoply of opportunities opened up. We identified over twenty types of activities conducted on iVisit (Laferrière, Breuleux, \& Inchauspé, 2004; Laferrière et al., 2008), thus bringing evidence that the introduction of this new tool change teachers' and school learners' learners interaction within and beyond their usual learning environment. For some teachers, however, iVisit was at the origin of a pedagogical tension (tension 2). This tool had also been chosen because it afforded verbal communication between pupils, instead of reproducing the typical model of interactions (Initiative-Response-Evaluation; IRE, Cazden, 1988; Meehan, 1978). This had some consequences on the tool's affordances: it didn't provide any kind of blackboard for teachers that wanted to use it in a more traditional 
PROBLEMS

OF EDUCATION

IN THE $21^{\text {st }}$ CENTURY

Volume 40, 2012

\section{Knowledge Forum as a tool for knowledge building}

Knowledge Forum (KF) was the tool used for written communication between students from different classrooms. As stated previously, it has strong roots in the knowledge building epistemology, theory and pedagogy (tension 3). Idea improvement is at the center of KF and its design is coherent with it. For instance, terminology used in the environment has a specific meaning. We don't write messages; we write notes. We don't answer a note; we build on it. Such expressions relate more with the main thrust of this tool: improvement. However, the conceptual coherence found by some didn't find all expected echoes when the tool landed in school districts. Some people, namely pedagogical consultants and IT specialists, found all these words overrated; it sounded like jargon to their ears and they rapidly concluded it was too hard to understand for young students, instead of taking the time to explain it to them. RIT was available to teachers interested in the tool, and offered numerous opportunities for discussion. Teachers who adopted the tool felt they had a loaded agenda having to serve both the requirements of the new curriculum and the requirements of the RNS initiative. The tension became overt during onsite/online professional activities, and got resolved for many of those who maintained an ongoing dialogue with RIT.

Another feature of KF that created tension was about its sober visual design, one aiming at progressive discourse instead of having students invest much time on peripheral tasks such as formatting. In counterpart, though, features such as bold, color picker, pictures insertion and so on are almost hidden in the software. At first sight, some people didn't find KF very attractive as it was a bit in contradiction with a more fashionable, colored and flourishing image of what ICTs should look like. Thus, they tended to conclude students would dislike it and knowledge building would not be possible in classes.

A few actions helped reduce the tension surrounding Knowledge Forum: accommodations regarding the ports and improvements to the tool. As for iVisit, its use lasted during the whole period but a web-based videoconferencing system, much praised by the IT services, was also promoted and used by RIT.

\section{Emerging Tensions Surrounding the Networked Classroom}

From the inception of the initiative and on, participants were invited to co-design the remote networked school/« classe en réseau »/enriched learning environment - objectsoutcomes towards greater educational success. Teacher participation in the decision-making process was considered an important condition for innovation at the local school level and beyond (Allaire et al., 2006 \& Laferrière et al., 2008). Therefore, top-down decisions kept appearing to some as being of a contradictory nature with bottom-up participation. Talking helped see the necessary dialectical coexistence of these two processes.

\section{Internal/external resources}

The introduction of the two collaborative tools in the classroom brought access to resources in the newly networked classroom. Before the RNS, many classrooms did not have large bandwidth access; most of them did not have Internet access at all. Only in a small number of classrooms, were teamwork or cooperative work already well established. The access to the videoconferencing system brought opportunity to interact in learning with students from distant classroom, experts, youth literature author, researcher, speech therapist, special education teacher. 
Thérèse LAFERRIÈRE, Sylvie BARMA, Fernand GERVAIS, Christine HAMEL, Stéphane ALLAIRE, Alain BREULEUX. Teaching, Learning, and Knowledge Building: The Case of the Remote Networked School Initiative

$\mid$\begin{tabular}{l} 
PROBLEMS \\
OF EDUCATION \\
IN THE $21^{\text {st }}$ CENTURY \\
Volume 40, 2012 \\
\hline 103
\end{tabular}

However, this was contrary to being the one-and-only teacher in the classroom (tension 4). Eventually, those new activities generated new rules and routines in the classroom, for example an increased number of cooperative activities that made sense with the new curriculum.

\section{Onsite/online learning}

Multigrade classrooms were commonplace in both elementary and secondary remote schools and their number increased throughout the eight-year period. Two grade classrooms became three grade classrooms and more, with a noticeable increase observed in Phase 3 (24 $\%$ of the classroom with more than 2 grades). It was not unusual to find school learners from one grade involved in individual tasks while the teacher was working with students from the other grade(s).

Diversity among students is a characteristic that brings value to a learning community. The organization of the classroom as a learning community was explicitly part of the pedagogy of the reform in Quebec. Among others, it meant to see students as resources for their peers (tension 5). Some multigrade classroom teachers saw new possibilities as they got to know the knowledge building principles, especially the Community Knowledge, Collective Responsibility principle (Scardamalia \& Bereiter, 2004). Figure 1 illustrates the transformation in the classroom organization for students and teachers as it presents the activity system for the student in a RNS classroom.

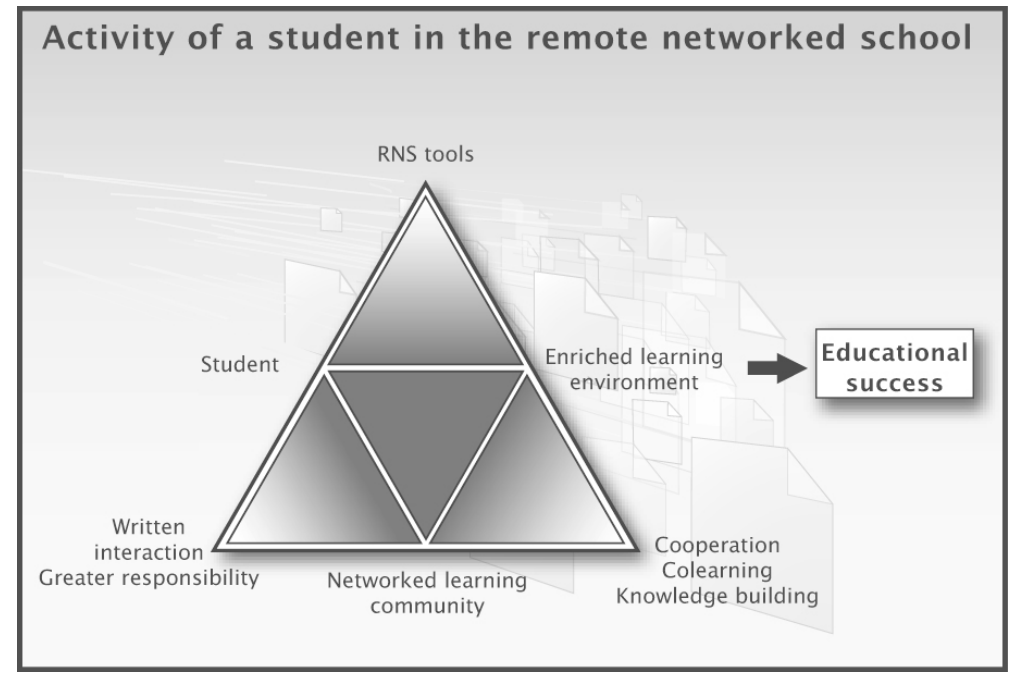

Figure 1: RNS student's activity system.

\section{Topic-centered/problem-centered collaborative inquiry}

Project- and inquiry-based learning and the classroom-based learning community model were new to almost all teachers (tension 6), let alone collaborative technologies and knowledge building. Teachers began to engage students in learning activities and projects conducted online (in collaboration with learners and teachers from other schools) once large bandwidth was reliable and basic use of tools mastered, and once some understanding of new pedagogical approaches was reached. Pedagogical use, however, did not depend only on technological means: in all phases of the initiative, some teachers in classrooms with lesser connectivity engaged school learners in collaborative inquiries of a greater complexity than some with better connectivity. 
PROBLEMS

OF EDUCATION

IN THE $21^{\text {st }}$ CENTURY

Volume 40, 2012

104

RIT focused on the knowledge building principle Authentic questioning, and real ideas (Scardamalia \& Bereiter, 2004), which was well aligned with the new national curriculum (tension 7). RIT offered onsite and online professional development activities regarding how student-driven questions were important for discourse to take off in Knowledge Forum. Teachers noted that working on authentic problem with distant colleague in an inquiry mode put more responsibility in the student hand. For RIT a new division of labor was taking place: The new rules in classrooms were defined to let student(s) worked with distant peer(s) with autonomy and teacher mediation (Figure 1). There were signs that students were beginning to build knowledge together. Teachers transformed their image of what students could do (Laferrière et al., 2004) but kept being highly challenged by the practice of a knowledge building pedagogy, and even more so when research results showed a large part of authentic questioning. The very use of Knowledge Forum kept raising the bar of what could be accomplished (Laferrière et al., 2010).

\section{Individual learning/collaborative learning/knowledge building}

The student as central was a leitmotiv, and individual learning remained highly promoted even in the midst of the educational reform. School district based teacher educators prepared materials and gave workshops devoted to this orientation. Writing and reading to and for each other in the Knowledge Forum allowed an authentic interaction that implied a greater responsibility for the students and the ideas they explained to the networked learning community they were part of (tension 8).

Teachers observed that students were more interested in writing since they began writing in Knowledge Forum. Teachers who devoted more time for classes to engage in knowledge building began to see transformative classroom discourse through research results reported during iterations (e.g., figure 2).

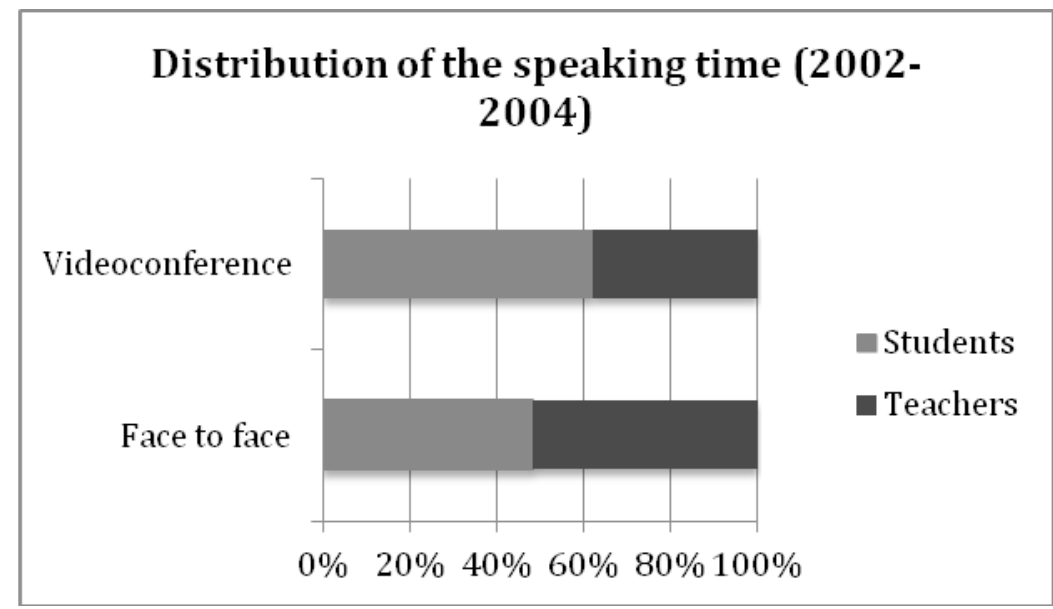

Figure 2: Distribution of speaking time in the RNS classroom (Phase One 20022004).

RIT reported on the author of the third note in forum threads (figure 3), an interesting departure of what is usually observed in a classroom (Initiative-Response-Evaluation, Cazden, 1988). RIT also reported (figure 4) on the broad variety of questions (task-orientation questions, long-answer seeking question, short-answer seeking questions) identified in the online discourse using a grid for face-to-face group interaction when members are engaged in problem-based 
Thérèse LAFERRIÈRE, Sylvie BARMA, Fernand GERVAIS, Christine HAMEL, Stéphane ALLAIRE, Alain BREULEUX. Teaching, Learning, and Knowledge Building: The Case of the Remote Networked School Initiative

learning (Hmelo-Silver \& Barrows, 2008). Furthermore, results regarding the explanation level Volume 40, 2012 reached by students showing more difficulty than others at the onset were most encouraging 105 (Hamel, Turcotte, \& Laferrière, in progress).

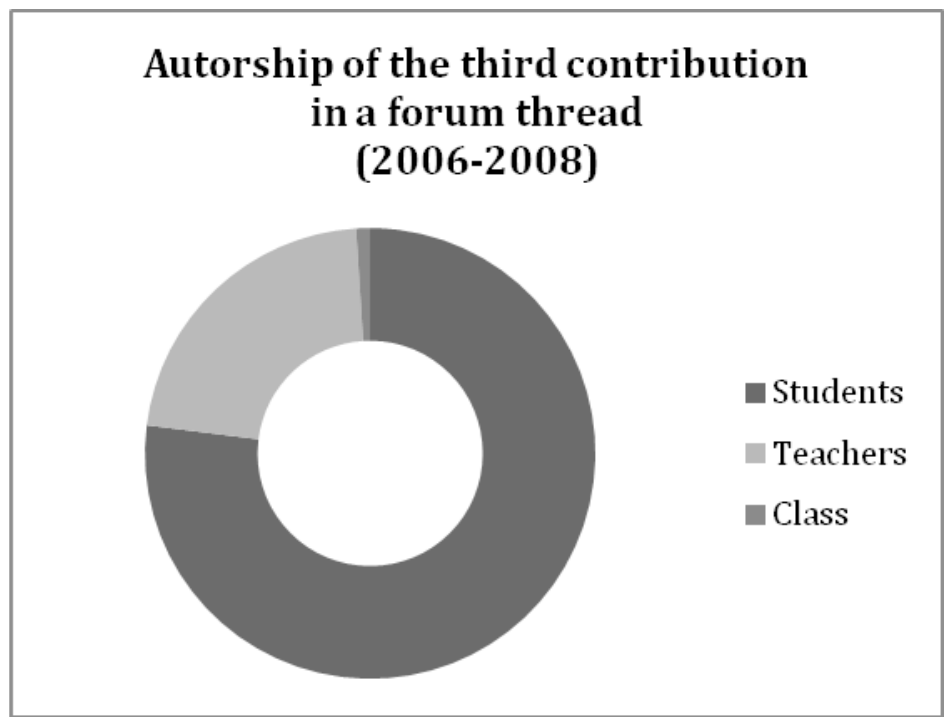

Figure 3: Authorship of the third contribution in a forum thread (Phase Two - 2006-2008).

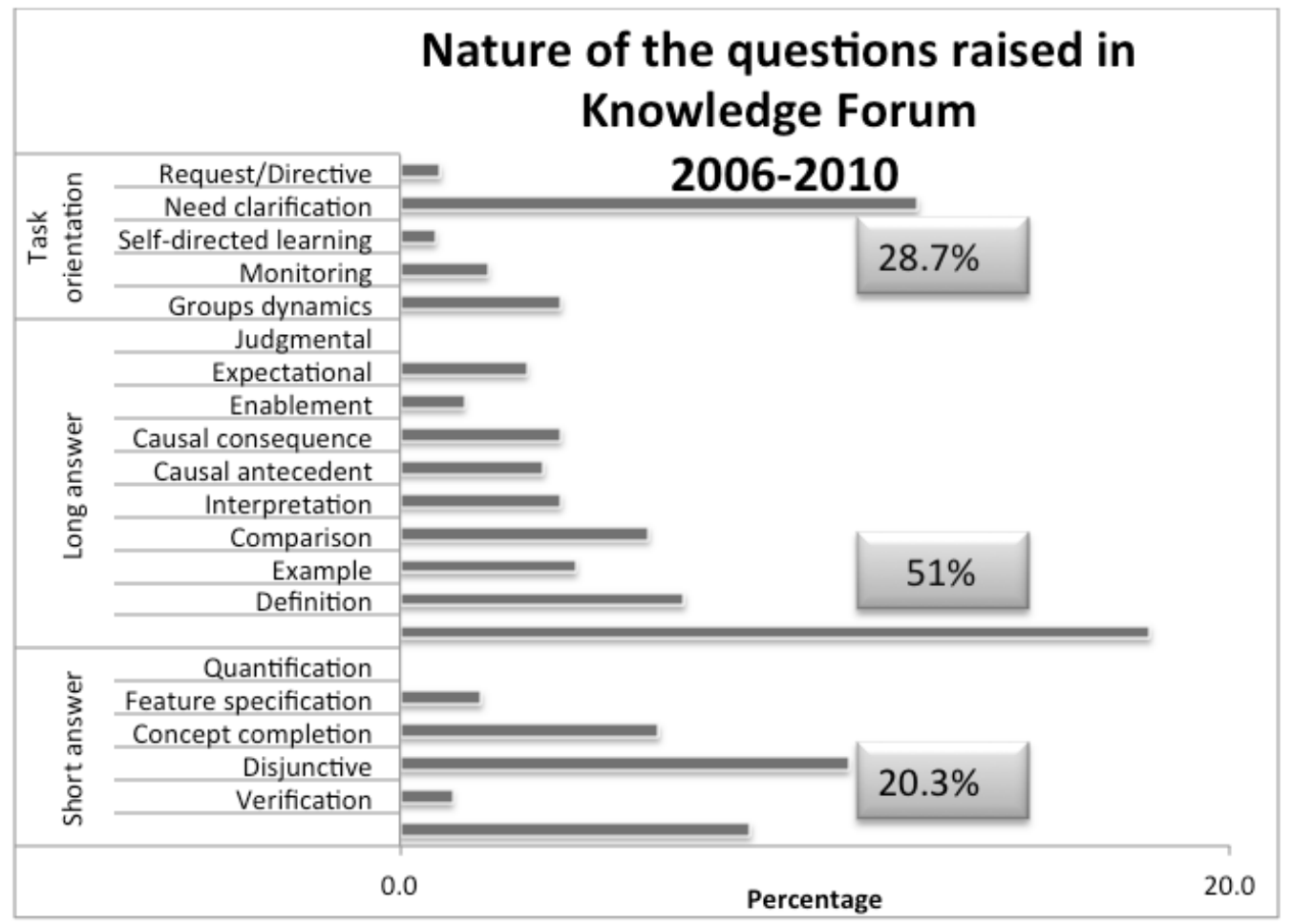

Figure 4: Distribution of the questions asked in the forum (Phases 2 \& 3 - 20062010). 
PROBLEMS

OF EDUCATION

IN THE $21^{\text {st }}$ CENTURY

Volume 40, 2012

106

\section{Tensions with Third Organization Activity Systems}

Understanding the role of third-party organizations

The RNS initiative gave central stage to a knowledge transfer organization. This means that the Ministry of Education had CEFRIO as its primary partner. This "triangle" was new for the participating university researchers (tension 9). Discussions were necessary for clarifying roles, and finding complementarities. In 2011, researchers from four universities, Laval University, McGill University, University of Quebec at Chicoutimi and University of Quebec in Outaouais, continue to interact, primarily online and at each CEFRIO's knowledge transfer session (one per year), with school districts, school principals and teachers.

RIT's role also needed to be clarified. Some of its members were more involved in intervention, and others in research. On the intervention side, RIT did not provide typical professional development activities such as onsite presentations. Rather, it relied on reflection on action within the TACT iVisit virtual room. In the later years it offered a series of planned seminars on VIA. RIT is part of a knowledge building international network through the Institute for Knowledge Innovation and Technology based at the University of Toronto. This network is composed of scholars in the learning sciences domain interested in effective use of ICTs in the classroom. Therefore, the use of technology that seemed to have little educational potential was seen by researchers as too much time consuming in classrooms (tension 10). More deeply, the tension was between the valuing of knowledge-centered activities and the valuing of "distracting" or "amusing" activities for students. There was some teachers who, as they engaged themselves in a graduate program with a strong knowledge building emphasis, had difficulty to deal with formal requirements and even with written online discourse, although they appreciated and found helpful, for their professional development, the possibility of meeting other participants every week on a schedule.

\section{Individual/co-teaching}

To be part of the RNS initiative was seen by teachers as a move away from isolated practice. Teachers teamed up according to their interests and the needs of their respective class in learning outcomes, mainly inquiries in science and social studies, two learning domains that were more poorly covered before in their classroom (Allaire et al., 2006). The teacher activity system transformed in the sense that networked co-teaching began to occur (see Figure 5) between teachers of different classrooms.

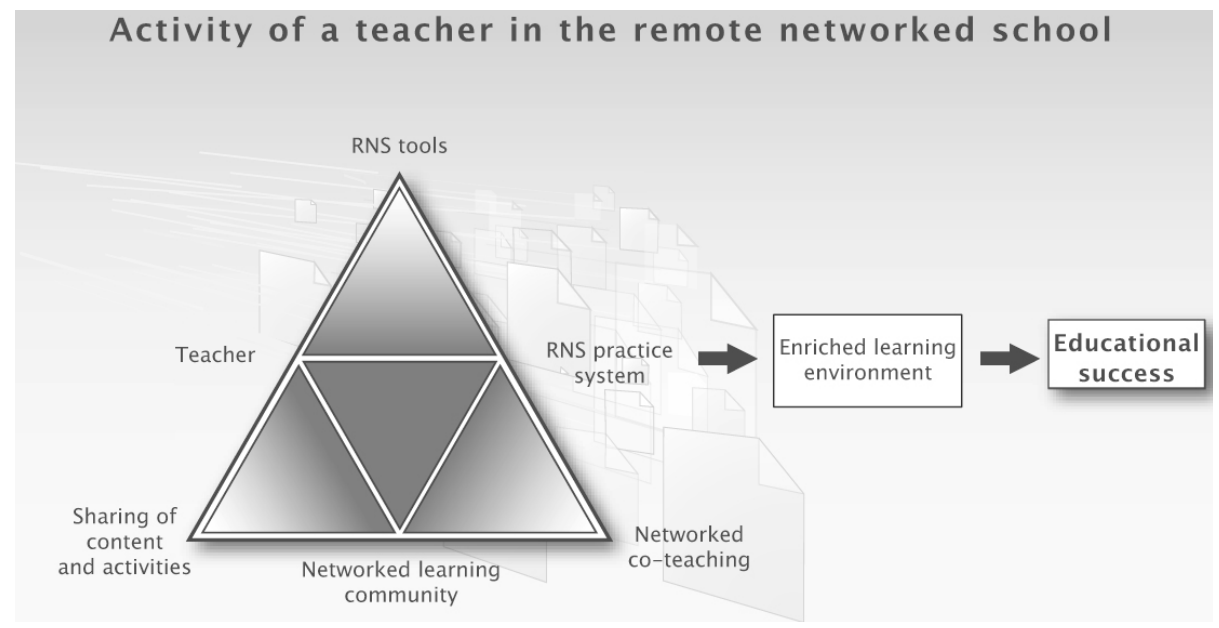

Figure 5: RNS teacher's activity system. 
Thérèse LAFERRIÈRE, Sylvie BARMA, Fernand GERVAIS, Christine HAMEL, Stéphane ALLAIRE, Alain BREULEUX. Teaching, Learning, and Knowledge Building: The Case of the Remote Networked School Initiative

$\mid$\begin{tabular}{l} 
PROBLEMS \\
OF EDUCATION \\
IN THE 21 $1^{\text {st }}$ CENTURY \\
Volume 40, 2012 \\
\hline 107
\end{tabular}

As the institutionalization of the RNS model loomed, some feared that "mandatory collaborative teaching" might be the rising norm (tension 11). Earlier top-down attempts to pair teachers with one another led to some frustrations within some school districts. The teacher union was monitoring closely school districts' and schools' decisions in this regard.

Transformations at one level created both tensions and satisfactions at another level. To understand "second-loop tensions" within and between the RNS activity systems, RIT turned to Engeström's later works.

\section{Integrating the Analysis of Contradictions as Driving Forces to Document an Expansive Cycle}

The seven phases of what Engeström (1987) identifies as the cycle of expansive learning in the context of developmental research are reflected in the previous account. First, we provide an overview of this cycle (Figure 6). Second, each phase is further discussed.

The first phase refers to the need state, the first level of contradictions, and constitutes the basic inner contradiction that can become a driving force for the overall activity. The RNS initiative was not the result of a bottom up process but was rather imposed to volunteer participants (school districts, school principals, teachers). The two collaborative technologies galvanized the initiative.

Contradictions need to be discussed once they have been introduced. The second phase or set of actions was that of analyzing the situation, that is, the opportunity for co-teaching and co-learning between classrooms, by developing a picture of its inner systemic. Solutions were offered to the problematic situation: the proposed model was the networked classroom. The new model was then analysed in order to grasp its potential and limitations, and especially those of collaborative technologies/pedagogies. We identified those phases as part of the second level of contradictions.

Implementing the model was the third level of contradictions: New ways of engaging in the co-design of the RNS (activity) emerged and a new organization appeared, that of the knowledge building oriented networked classroom in a small remote school. Soon enough, our analysis illustrated how multiple activity systems came into relation and conceptual expansion took place.

The sixth and seventh actions (reflecting and consolidating on the practice) led to the quaternary contradiction. It taught us how critical the role of third organizations, the knowledge transfer organization (CEFRIO) and an international network under the leadership of Scardamalia and Bereiter (Institute for Knowledge Innovation and Technology, IKIT), was and developed in the form of a new thirdness actually under implementation (KBIP) as we hope that this outcome will consolidate into a new stable form of practice. 
PROBLEMS

OF EDUCATION

IN THE $21^{\text {st }}$ CENTURY Volume 40, 2012

\section{Consolidating the new practice: Participation in KBIP}

6. Reflecting on the process: Critical role of the knowledge transfer organization (CEFRIO)

\section{Implementing the new model: The emerging organization of the KB-oriented networked classroom}

4. Examining the new model: Underuse of Knowledge Forum
1. Questioning: Dissatisfaction with the status quo

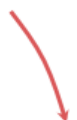

2. Double bind analysis: Use and exchange of iVisit and KF (new tools)

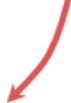

3. Modeling the new solution: Networked classrooms/learning communities

Source: Engeström, Y. (1987). Learning by expanding: An activity-theoretical approach to developmental research. Helsinki: Orienta-Konsultit. (available online at: http://lchc.ucsd.edu/MCA/Paper/Engestrom/expanding/toc.htm)

12-03-10 ब 2003 Center for Activity Theory and

Figure 6: The expansive cycle of the RNS initiative.

\section{Phase 1: Questioning - Dissatisfaction with the status quo}

The Ministry of Education and CEFRIO questioned the status quo with the RNS initiative (contradiction level one). The former was seeing demographics changing in small remote areas and was wondering how long they could afford financing the remote schools at the level they were. The Deputy Minister also wondered whether ICTs could support alternative action. CEFRIO accepted the Ministry's mandate. The RNS became known as CEFRIO's project.

IT is by far preferable, as emphasized by Looi, So \& Chen (2010), that top-down decisions be accompanied by bottom-up desire. Dissatisfaction with the status quo (one of Ely's conditions for innovation with ICTs, 1991) was not highly felt at the school district nor at the school level. Among local participants, research (Turcotte and Hamel, 2008) showed that teachers were the ones most dissatisfied with the status quo. Early adopters of the RNS tools were the ones to manifest « desire» more clearly.

\section{Phase 2: Double blind analysis - Use and exchange of iVisit and KF (new tools)}

The RNS model put forward two collaborative tools that had the power to support collaboration at a high level. However, this action created a double-bind due to the use and exchange values they introduced in the schools (contradiction level 2). The requirements of use of the videoconferencing system (iVisit) confronted (tension 1) local practices (IT services and pedagogical practices).

IT services had to open their network as specific ports needed to be open for iVisit (a client/server tool) to operate on their network. They felt it as a breach of security but, at the same time, it provided teachers and school principals with a highly functional multi-user videoconferencing system to network schools and classrooms. However, teachers use of iVisit confronted them with another tension, that of student active participation (tension 2). As webbased videoconferencing systems came to exist, most IT services strongly wanted to get one, thus satisfying their desire to only open port 80 (web port) and freeing themselves from installing 
Thérèse LAFERRIÈRE, Sylvie BARMA, Fernand GERVAIS, Christine HAMEL, Stéphane ALLAIRE, Alain BREULEUX. Teaching, Learning, and Knowledge Building: The Case of the Remote Networked School Initiative

iVisit on every RNS computer. Therefore, iVisit use as an exchange value began to drop in 2008, and transition towards a web-based videoconferencing system (VIA) was completed in 2010.

As for Knowledge Forum, it was seen by curriculum counsellors and technology support personnel as a difficult tool for teachers and students to use (tension 3). The latter were eager to suggest other ICTs they had recently learned to use (blog, wiki). They had a responsibility to fulfill with their school district, that of infusing new technology. Meanwhile, the RNS initiative had an obligation of results well beyond the use of new technology, and that obligation strongly weighted in favour of the KF. As changes in classroom interaction patterns, classroom discourse and learning outcomes began to manifest, KF's exchange value was in progression.

\section{Phase 3: Modeling the new solution - Networked classrooms/learning communities}

The networked classroom allowed access to external resources (tension 4) and students became resources for distant peers (tension 5). The concept of the learning community, which was already promoted in curricular materials, brought new meaning to the notion of the multigrade classroom and the diversity of students with whom the teacher had to work with. The learning community was a central feature of a one-to-one laptop program with which some classrooms began to interact, and modelling was in effect. RNS students' new learning environment was resolving one aspect related to the secondary contradiction and making learning outcomes possible. Exemplars of the application of both concepts (networked classroom and learning community) were provided at onsite professional development sessions and during online conversations with teachers on iVisit. RIT used these concepts as scaffolds towards knowledge building pedagogy, especially the knowledge building principles (Scardamalia \& Bereiter, 2004).

\section{Phase 4: Examining the New Model - Underuse of Knowledge Forum}

RIT and a good number of teachers made use of the concept of knowledge building (contradiction 2). "Investigation collective"/collaborative inquiry was a related and easier concept to grasp (tension 6) than knowledge building/ " coélaboration de connaissances ") - see also the term progressive inquiry used by classes studied by Hakkarainen (2003). Nonetheless, RIT was noticing that the advanced functions of Knowledge Forum, a tool filled with affordances for knowledge building, were underused: keywords, rise-above notes, note reference, quotations, note publication and analytical tools.

Phase 5: Implementing the New Model - The emerging organization of the KB-oriented networked classroom

A networked classroom could engage in any kind of online activity. The knowledgebuilding oriented networked classroom (contradiction 3) is characterized by progressive discourse onsite and online (tensions 7,8 and 10). There are clear signs that the RNS initiative had made headways in implementing this model. In best cases, teachers engaged students in collaborative inquiry one hour a day or during $20 \%$ of classroom time. Allaire et Lusignan's (2011) book was written by RNS teachers and for RNS teachers with the facilitation of a researcher and a professional writer.

Phase 6: Reflecting on the process - Critical role of the knowledge transfer organization (CEFRIO)

As illustrated along in this paper, tensions accumulated within and between activity 
PROBLEMS

OF EDUCATION

IN THE $21^{\text {st }}$ CENTURY

Volume 40, 2012

110

systems. When the activity system we presented adopted an object from the outside (such as a tool like iVisit or KF) through its interaction with another activity system (RIT), disturbances were created and we were able to analyze the emerging tensions and understand them as manifestations of contradictions. In Phase 6 of the cycle of expansion, we can see that at least one other activity system (CEFRIO) shared the same object in the transformation of the learning environment of the remote networked school. CEFRIO was the coordinating body, and this is why at this point, we choose to put some emphasis on its contribution. It played a key role to trigger, keep and sustain the changes in action over the years (contradiction 4).

As an organization that works in many sectors whose organizations are integrating ICTs, CEFRIO brought its knowledge transfer expertise to the RNS initiative, and transformed researchers' previous experience (tension 9) in university-school partnerships (Laferrière, Erickson, \& Breuleux, 2007). Researchers gained a better understanding of CEFRIO's role in coordinating and managing the initiative and especially with regard to sustainability and scalability issues.

Looi et al (2010) reported on the Singapore experience, an even more encompassing systemic analysis, and referred to Coburn's (2003) definition of scale as "encompassing four interrelated dimensions: depth, sustainability, spread, and shift in reform ownership".

Depth refers to deep and consequential change in classroom practice, altering teachers' beliefs, norms of social interaction, and pedagogical principles as enacted in the curriculum. Sustainability involves maintaining these consequential changes over substantial periods of time, while spread is based on the diffusion of the innovation to large numbers of classrooms and schools. Shift requires districts, schools, and teachers to assume ownership of the innovation, deepening, sustaining, and spreading its impact. (p. 16).

Over the eight-year period, the RNS model went to scale in Coburn's terms (2003). Moreover, as it proved to be sustainable with an increasing number of classrooms and schools, it evolved - see Dede (2005) who added a fifth dimension to Coburn's definition of scale, namely, evolution, in which the innovation, is revised by adaptors. The RNS model, with its emphasis on knowledge building, is beginning to reach other Francophone countries such as Burkina Faso, France and Morocco.

The 2010-2012 period is a transition one meant to result in a shift of ownerships. However, issues related to co-teaching are not yet resolved (tension 11), and will have to be resorbed for better scaling of the model.

\section{Phase 7: Consolidating the New Practices - Participation in KBIP}

Another third organization played a critical role (contradiction 4), the network of researchers and teachers part of IKIT. It is at one of their summer institute that the Knowledge Building International Project (KBIP) was initiated. It created a critical mass of emerging knowledge building-oriented networked classrooms, thus offering opportunities for teachers to move beyond their context-based understanding of knowledge building and local practices (Laferrière et al., 2011; Laferrière, Law, \& Montané, in press).

\section{Conclusions}

The RNS initiative was analyzed from the point of view of Engestrom's activity theory framework, and borrowing above all his concept of expansive cycle. Understanding the RNS's complex situation through activity systems analysis made it possible for RIT to take action by developing instruments for generating new interventions and sustaining progress over the 
Thérèse LAFERRIÈRE, Sylvie BARMA, Fernand GERVAIS, Christine HAMEL, Stéphane ALLAIRE, Alain BREULEUX. Teaching, Learning, and Knowledge Building: The Case of the Remote Networked School Initiative

years. The exercise led to a better understanding of the tensions and contradictions that marked the unfolding of this innovation.

The identification of tensions and contradictions within the RNS activity system offered a sociocultural analysis of the complex process of integrating into classroom practice two specific collaboration technologies, one for written online asynchronous discourse and the other for verbal synchronous discourse. Whereas a social need provided the impetus for the RNS initiative, constructivist pedagogies, and especially knowledge building, provided the pedagogical rationale.

As a result, the affordances of Knowledge Forum and the knowledge building pedagogy are better understood in Quebec, even though collaborative tools that can be used in a networked classroom are multiplying.

Another impact of this initiative was to strengthen a sense that school innovation could happen, and learning outcomes could expand. A thirdness, which reflects the overcoming of four-level of contradictions over an eight-year period, is presented as an outcome of Engeström's (1987) cycle of expansive learning. Phase Five is underway, and capacity transfer is the challenge as universities' role in the initiative will be lessened and training capacity transferred to senior RNS participants.

Nevertheless, one is left with an understanding that school innovation, especially ones of the kind that aim at student deep understanding and knowledge building, is a long and complex process. Deep understanding and knowledge creation are two of three UNESCO (2011) ICT competency standards for teachers. Teachers and teacher educators have a long way to go.

\section{Acknowledgements}

Researchers are grateful to all the RNS participants, CEFRIO, and the Quebec Ministry of Education, Canada.

\section{References}

Allaire, S., \& Lusignan, G. (2011). Enseigner et apprendre en réseau : collaborer entre écoles distantes à l'aide des TIC. Anjou, Montréal: Éditions CEC.

Allaire, S., Pellerin, G., Beaudoin, M., Couture, C., \& Turcotte, S. (2010). Développement d'un programme de formation interuniversitaire en réseau: pallier une situation découlant des mouvements démographiques au Québec. Journées Communication et Apprentissage Instrumentés en Réseau (JOCAIR 2010), Amiens.

Allaire, S., Beaudoin, J., Breuleux, A., Hamel, C., Inchauspé, P., Laferrière, T., \& Turcotte, S. (2006). L'école éloignée en réseau. Rapport de recherche, phase II, CEFRIO, Québec.

Banathy, B. H. (1991). Systems design of education: A journey to create the future. Englewood Cliffs, NJ: Educational Technology Publications.

Barab, S. A., Barnett, M., \& Squire, K. (2002). Designing an empirical account of a community of practice: 906 Characterizing the essential tensions. Journal of the Learning Sciences, 11 (4), 489-542.

Bereiter, C., \& Scardamalia, M. (1993). Surpassing ourselves: An inquiry into the nature and implications of expertise. Chicago and La Salle, IL: Open Court.

Brown, A. L. (1992). Design experiments: Theoretical and methodological challenges in creating complex interventions in classroom settings. The Journal of the Learning Sciences, 2 (2), 141-178.

Dede, C. (2005). Scaling Up: Evolving Innovations beyond Ideal Settings to Challenging Contexts of Practice. In R.K. Sawyer (Ed.), Cambridge Handbook of the Learning Sciences. Cambridge, England: Cambridge University Press.

Coburn, C. (2003). Rethinking scale: Moving beyond numbers to deep and lasting change. Educational Researcher, 32 (6), 3-12. 
PROBLEMS

OF EDUCATION

IN THE $21^{\text {st }}$ CENTURY

Volume 40, 2012

112 Collins, A, Joseph, D., \& Bielaczyc, K. (2004). Design Research: Theoretical and Methodological Issues. Journal of the Learning Sciences, 13 (1), 15-42.

Engeström, Y. (1987). Learning by expanding. An activity-theoretical approach to developmental research. Helsinki: Orienta-Konsultit.

Engeström, Y., \& Miettinen, R. (1999). Introduction. In Engeström Y., Miettinen R., \& Punmamäki R. (Eds.), Perspectives on activity theory (pp. 1-18). New York: Cambridge University Press.

Engeström, Y., \& Sannino, A. (2010a). Discursive manifestations of contradictions in organizational change efforts. A methodological framework. Journal of Organizational Change Management, 24 (3), 368-387.

Engeström, Y., \& Sannino, A. (2010b) Studies of Expansive Learning: Foundations, Findings and Future Challenges. Educational Research Review, 5 (1), 1-24.

Hakkarainen, K. (2003). Progressive inquiry in a computer-supported biology class. Journal of Research in Science Teaching, 40 (10), 1072-1088.

Hamel, C., Turcotte, S., \& Laferrière, T. (in progress). Improving students' understanding and explanation skills through the use of a knowledge building online suite of tools.

Hollan, J., Hutchins, E., \& Kirsch, D. (2000). Distributed cognition: Toward a new foundation for humancomputer interaction research. ACM Transactions on Computer-Human Interaction, 7 (2), 174196.

Holmes Group (1990). Tomorrow's schools: A report of the Holmes Group. East Lansing, MI.

Laferrière, T., Breuleux, A., \& Inchauspé, P. (2004). L’école éloignée en réseau. Rapport de recherche, phase I, CEFRIO, Québec.

Laferriere, T., Erickson, G., \& Breuleux, A. (2007). Innovative Models of Web-supported UniversitySchool Partnerships. Canadian Journal of Education, 30 (1), 211-238 (online).

Laferrière, T., Allaire, S., Breuleux, A., Hamel, C., Turcotte, S., Gaudreault-Perron, J., Inchauspé, P., \& Beaudoin, J. (2008). L’école éloignée en réseau: L’apprentissage des élèves. Rapport de recherche, phase III, CEFRIO, Québec. Available: http://www.eer.qc.ca/doc/2009/EER_rapportsynthese_phase-3.pdf.

Laferrière, T., Montane, M., Gros, B., Alvarez, I., Bernaus, M., Breuleux, A., Allaire, S., Hamel, C., \& Lamon, M. (2010). Partnerships for Knowledge Building: An Emerging Model. Second special edition on knowledge building, edited by M. Scardamalia \& B. Egnetoff. Canadian Journal of Learning Technologies, 36 (1), 1-20.

Laferrière, T., Hamel, C., Allaire, S., Turcotte, S., Breuleux, A., Beaudoin, J., \& Gaudreault-Perron, J. (2011). L'école éloignée en réseau: L'apprentissage des élèves. Rapport-synthèse, CEFRIO, Québec.

Laferrière, T., Law, N., Montané, M. (in press). An international knowledge building network for sustainable curriculum and pedagogical innovation. International Education Science, 5 (3).

Lieberman, A. (2000). Networks as learning communities: Shaping the future of teacher development. Journal of Teacher Education, 51 (3), 221-227.

Looi, C. K., So, H. J., Toh, Y., \& Chen, W. (2010). The Singapore experience: Synergy of national policy, 4 classroom practice and design research. International Journal of Computer-Supported Collaborative Learning, 6 (1), 9-37.

Salomon, G. (Ed.). (1993). Distributed cognitions: Psychological and educational considerations. New York: Cambridge University Press.

Scardamalia, M., \& Bereiter, C. (1994). Computer support for knowledge-building communities. The Journal of the Learning Sciences, 3 (3), 265-283.

Scardamalia, M., \& Bereiter, C. (2004). Knowledge Building. In Encyclopedia of Education Second Edition. New York: Macmillan Reference.

Schön, D. A. (1983). The reflective practitioner: How professionals think in action. New York: Basic Books. 
Thérèse LAFERRIĖRE, Sylvie BARMA, Fernand GERVAIS, Christine HAMEL, Stéphane ALLAIRE, Alain BREULEUX. Teaching, Learning, and Knowledge Building: The Case of the Remote Networked School Initiative

$\mid$\begin{tabular}{l} 
PROBLEMS \\
OF EDUCATION \\
IN THE $21^{\text {st }}$ CENTURY \\
Volume 40, 2012 \\
\hline 113
\end{tabular}

Silva, M., \& Breuleux, A. (1994). The use of participatory design in the implementation of internet-based collaborative learning activities in K-12 classrooms. Interpersonal Computing and Technology: An Electronic Journal for the 21st Century, 2, pp. 99-128. Retrieved August 15th, 2011, from http://www.helsinki.fi/science/optek/1994/n3/silva.txt

Turcotte, S., \& Hamel, C. (2008). Necessary conditions to implement innovation in remote networked schools: The stakeholders' perceptions. Canadian Journal of Learning and Technology/Revue canadienne de l'apprentissage et de la technologie, 34 (1), 91-105.

UNESCO (2008). ICT competency standards for teachers. Paris: UNESCO. Retrieved from http:// unesdoc.unesco.org/images/0015/001562/156207e.pdf

Advised by Rita Makarskaitè-Petkevičienè, Lithuanian University of Educational Sciences, Lithuania

Received: February 27, 2012

Accepted: March 11, 2012

\begin{tabular}{|ll|}
\hline Thérèse Laferrière & PhD, Professor, Faculty of Science Education, Université Laval, 2320, \\
Street des Bibliothèques, Québec, Canada. \\
E-mail: Therese.Laferriere@fse.ulaval.ca
\end{tabular}

